\title{
A Study of Quality Assessment in Higher Education within the Context of Sustainable Development: A Case Study from Czech Republic
}

\author{
David Vykydal ${ }^{1}$, Martin Folta ${ }^{2, *(1)}$ and Jaroslav Nenadál ${ }^{1}$ \\ 1 Department of Quality Management, Faculty of Materials Science and Technology, VSB-Technical University \\ of Ostrava, 17. listopadu 2172/15, 70800 Ostrava-Poruba, Czech Republic; david.vykydal@vsb.cz (D.V.); \\ jaroslav.nenadal@vsb.cz (J.N.) \\ 2 Department of Production, Logistics and Quality Management, Škoda Auto University, Na Karmeli 1457, \\ 29301 Mladá Boleslav, Czech Republic \\ * Correspondence: martin.folta@savs.cz
}

Received: 3 May 2020; Accepted: 9 June 2020; Published: 11 June 2020

check for updates

\begin{abstract}
Quality has become an increasingly important and critical success factor at higher education institutions, particularly universities. Numerous discussions have been held about education quality in the context of sustainable development. However, the quality of that education strongly depends on the overall quality of the management system which operates at schools. The principal aim of this article is to present the approaches to the quality management systems' development and their assessment at universities, and share some lessons learned from this area of research. Some possibilities of the ISO 9001 standard's implementation, as well as the application of excellence models as a response to community demands, will be discussed, especially in the context of the recently-introduced Act No. 111/1998 Coll on Higher Education Institutions, which requires quality assurance and quality evaluation. A case study from The VSB-Technical University of Ostrava shows approaches, results and effects of the quality management system implementation.
\end{abstract}

Keywords: quality; sustainable development; quality management; organizational excellence; higher education institutions; EFQM Excellence Model

\section{Introduction}

Quality and quality management systems are not simply abstract concepts which are confined only to manufacturers or industrial plants, especially in today's world, where the development of these systems extends to all areas of life throughout the world, particularly high schools and universities. A higher level in the overall quality of education in higher education institutions is a necessary prerequisite to equip students with the knowledge, skills and the competences that they need to be successful after graduation. For this reason, each high school or university needs a functional and comprehensive quality management system. Such a system (which must be a natural part of a school's overall management system) allows people to have confidence in the performance of higher education institutions.

First of all, we need to point out that three different concepts for quality management system development and implementation can be generally distinguished at present:

(a) The ISO 9000 concept based on the application of the ISO 9001 standard's requirements [1] and the ISO 9004 standard's recommendations [2]. Many higher education institutions throughout the world (including some from the Czech Republic) have such systems certified to the ISO 9001 standard by accredited certification bodies. 
(b) The branch standard concept; various branches of business create their own quality management standards (they are usually improved by the ISO 9001 standard's requirements). The automotive sector, pharmaceuticals, telecommunications or other industries can serve as relevant examples. Such documents as [3-5] are adapted for this concept in the field of higher education.

(c) The organization's excellence concept, based on various excellence models. The European Foundation for Quality Management provides EFQM Excellence Model [6] or Baldrige criteria [7] can serve as an excellent example for all types of higher school or universities. The European Association for Quality Assurance in Higher Education (ENQA) published a special guideline within this concept in 2014 [8].

These concepts present a suitable direction for practical application within a higher education institution's environment. It is necessary to point out that after 1990, the attitudes of university leaders rapidly changed, due to the requirements of various stakeholders to present a clear demonstration of all the universities' activities and results. Consequently, quality management systems were gradually recognized as a valuable supporting tool. These systems compel all higher education institutions:

- to define strategy and policies,

- to utilize all resources (including people) by effective and efficient methods,

- to transform stakeholders' requirements into attractive and modern study programs or research outcomes,

- to control all internal processes, and lastly,

- to satisfy relevant segments of customers, including students or employees.

Such trends became an integral part of any Czech high school's approach to education quality, and therefore could no longer be dismissed as unnecessary. Our research, as well as proposals, were provided, on the following conditions:

(a) A definition of the quality of an organization which was established by ISO 9004:2018 standard is an appropriate and concise definition. It says that "the quality of an organization is a reflection of the inherent characteristics of an organisation to fulfil the needs and expectations of its customers and other interested parties, in order to achieve sustained success" [2].

(b) The quality of the organization (meaning higher education institutions in this case) is considered as an umbrella term, covering such aspects as performance, sustainable development or corporate social responsibility.

(c) The most frequent definition of sustainable development is defined by the World Commission on Environment and Development (Brundtland Commission), which states that "the development that meets the needs of the present without compromising the ability of future generations to meet their own needs." See also $[9,10]$, where the impact of sustainable development on universities is presented too.

(d) So-called "organizational excellence" must be understood as the highest level of the quality of an organization. M. Webster says that "organisational excellence is the delivering, and sustaining the delivery of, outstanding value to all key stakeholders" [11]. The American Society for Quality (ASQ) has defined this term: "Organisational excellence is defined as the ongoing efforts to establish an internal framework of standards and processes intended to engage and motivate employees to deliver products and services that fulfill customer requirements within business expectations. It is the achievement by an organisation to give a consistent superior performance-for example, outputs that exceed meeting objectives, needs, or expectations." [12]. According to the European Foundation for Quality Management (EFQM), "Excellent organisations are those that achieve and sustain outstanding levels of performance that meet or exceed the expectations of all their stakeholders" [6]. The real state of arts in the field of organizational excellence in the Czech Republic was investigated at an earlier time-see [13] for further details. 
(e) The version of EFQM Excellence Model from 2013 [6], which is generally recognized as the most advanced and comprehensive tool for achieving an organization's excellence, also includes criteria titled "Creating Sustainable Values". These criteria cover all key and main processes: from designing value on the one hand, to delivering value to interested parties on the other hand.

(f) That is why the EFQM Excellence Model was selected as a relevant basis for the quality assessment in Czech higher education institutions.

The principal goal of this paper is to present the approaches to the quality management systems development and their assessment at universities, to share some lessons learned from this area of research, through a case study from the Czech Republic.

\section{Literature Review: Quality in Higher Education}

Numerous studies and articles have been published since 1990, which have investigated and focused on the various aspects or issues of quality in higher education, see [14-22] for example. A lot of different opinions have been studied in this area up until now. Most of them argue that the quality in higher education is unclear and multidimensional term-see $[23,24]$. However, some other views and opinions related to the quality in higher education institutions can now be referred to. For example, Md. Moazzem Hossain and Mohammad Alamgir Hossain have performed their study as the first-reported initiative in higher education research, that explains quality management as a multi-order hierarchical reflective model. The quality management of the higher education system can be explained as a third-order model, where quality management is reflected by educational, administrative, and societal qualities [25]. Mrs. Sarah Spencer-Matthews from the Faculty of Business at the University of Southern Queensland in Brisbane (Australia) presented a case study using action research as an attempt to implement a quality management system in an academic department in a higher education institution. She argues that technical change is readily attained whilst the adoption of a quality culture achieves only token acceptance [26]. There was critical discussion about the dynamics behind the development and the internationalization of quality assurance policies and practices in higher education in Slovenia, by focusing on the establishment of the national quality assurance agency, on the introduction of the accreditation system and on institutional quality assurance development in the study realized by Hauptman Komotar [27]. In Europe, when adapting the so-called Bologna process, a special document titled Standards and Guidelines for Quality Assurance in the European Higher Education Area was published by ENQA [8]. J. Kohoutek gathered a lot of interesting findings about the practical implementation of this document, and some advantages and weaknesses of it, with respect to the accreditation process, are presented by Manatos and Huisman [28].

There are inherent strengths and weaknesses of the higher education system in the world. Three elements, development and structure, quality, and research capacity, were examined in a literature review by Ashour and Syeda Kauser Fatima [29] in the United Arab Emirates (UAE). The study has confirmed that a well-structured quality assurance system in place is one of the factors that can improve the quality of the education process. The mixed-method perspective on the investigation of determinants of effectiveness in quality assurance at the higher education institutions was presented by Seyfried and Pohlenz [30]. The survey data from German higher education institutions were collected to analyze the degree to which quality managers perceive their approaches to quality assurance as effective. The support by higher education institutions' higher management and cooperation with other education institutions are relevant preconditions for larger perceived degrees of quality assurance effectiveness [30].

The quality assessment is defined as a process of assessing the quality of what is provided by the organization to satisfy their customers. The assessment of a quality assurance system in the higher education process should be an integral part of a functioning university management system. Amin Y. Noaman et al. presented a developed higher education quality assessment model (HEQAM) that can be applied for the enhancement of university services [31]. It produces important recommendations for university's higher authorities to achieve the demanded quality services. 
The discussions so far on quality in higher education and its measurement are premised by Maureen Tam on two important considerations [32]: that the central activity of the higher education is that of maximizing the student's educational development; and that it is the continuing improvement to maximize student learning and development that remains the primary goal of universities and should be the focus of any concern over quality in higher education and its measurement. The measurement of the three quality dimensions (quality of design, quality of conformance and quality of performance) in higher education was conducted by Widrick et al. [33] The framework proposed and discussed in this study builds on the model developed by Mergen et al. [34] A set of measurements, along with some tools to measure the three dimensions of quality, were proposed. Many quality management initiatives, especially within service industries, die, because higher education organizations fail to measure outcomes. The proposed framework enables higher education organizations to better implement and measure quality initiatives [33,34].

An exploratory study examining the perceptions of university representatives about the quality was conducted in four public universities in the Kurdistan region of Iraq by Mr. Atrushi and Mr. Woodfield. It explores the higher education system from the perspective of the academic staff and university leaders, with a focus on evaluating the system's quality [35]. Additionally, clear differences in perceptions of what is quality in higher education were discovered between staff, students and employers [36]. Bennett analyses possibilities, shortcomings and advantages of the quality assessment in higher education [37]. Morosini et al. remind us that quality and performance measurement must be important part of quality management in the higher education institutions. They proposed and structured a set of performance indicators for five categories, as internationalization, management, teaching quality, pedagogical innovation and professional education or development [38].

\section{Materials and Methods}

The main objective of this article is to present the approaches to the quality management systems' development and their assessment at universities, as well as to share some lessons learned from this area of our research. In this section, we will present approaches, methods of empirical study and findings of our research and development activities focused on establishing the system's approach to the quality assurance and assessment in Czech universities. To obtain relevant results, 3 special conferences with representatives from more than 40 public, private and state Czech higher education institutions served in the initial method. Nearly 240 people participated in these conferences, including some rectors or vice rectors, chancellors and other universities' top management members. Semi structured interviews with representatives of these schools were held during these conferences, to investigate their opinions related to the necessity of quality management or their proposals on how such a management system should be implemented. We have chosen the semi structured interviews, as the questions are loosely structured and give respondents more opportunities to fully express themselves. The field research based on observations and a lot of various records review within these Czech universities followed to discover a current state of the quality assurance and quality assessment. Qualitative and quantitative data processing also contributed to achieve our goals. Learning from foreign good practice was provided through participating in some special conferences and by literature review. Finally, the pilot testing of developed assessment methods was used by the authors at 12 Czech universities.

First of all, we will provide a short description of the current state within Czech higher education institutions, as it seems to be necessary to understand a starting point of our research and development. A presentation of the fundamental steps and development activities of our original assessment of the quality in higher education will follow.

\subsection{The Current State of Quality Assessment at Czech Higher Education Institutions}

The Czech Republic has naturally accepted the Bologna process and all activities of ENQA are supported by the Czech Ministry of Education, Youth and Sport. This ministry formulated and launched a so-called Long-Term Plan for Educational, Scientific, Research, Development, Artistic and 
Other Creative Activities of Higher Education Institutions, in 2006. A special section included in this strategic document was titled "The Quality and Excellence of Academic Activities", where the fundamentals of quality assurance and quality assessment were described very clearly-see [19] for further details. The choice of study program accreditation as the main approach to the quality assessment of Czech higher education institutions is evident: although internal quality evaluations within the overall management system were voluntary activities (most Czech higher education institutions underestimated the importance of internal quality management systems from the beginning), external evaluations become compulsory and were carried out by the Accreditation Commission of the Czech Republic (AC). Special teams of experts were appointed to assess all designed study programs at higher education institutions. However, more and more managers from Czech higher schools and universities have come to gradually realize that there is a big difference between mere study program accreditation and comprehensive quality assurance or quality management. The investigations of the former Accreditation Commission were, for the most part, based on the traditional approach, where only achieved results were evaluated (the number of graduates, the number of articles published at journals with impact factor, the number of professors within the academic staff, etc.) On the other hand, the quality of internal processes and other enablers were completely ignored. That is why the top management of some Czech high schools or universities have started their quality journey from another perspective: they learned about, and adopted the positive experience from abroad and related it to the quality management of their own systems' development. Two alternatives arose on this journey: the ISO standards concept and the organization's excellence concept. These concepts are, at present, implemented more frequently in comparison to the ESG approach.

It is also important to note that the legal environment in this area also changed in 2016 [39]. The Act No. 111/1998 Coll. on Higher Education Institutions (The Higher Education Act) was finally upgraded, approved by the Parliament of the Czech Republic and released in April 2016. In this act, special attention is paid only to quality assurance and quality assessment in all types of Czech higher education institutions. Part 8 of this act, titled "Evaluation of Higher education institutions" states (in addition to other things):

- A higher education institution assures the quality of all its activities.

- The quality of the higher education institution's activities must be evaluated regularly.

- Such evaluation is performed both as internal and external evaluations. The external evaluation is conducted by a special Accreditation body.

- Each higher education institution must establish and maintain the quality assurance system of all its activities, based on:

1. defining mission and strategy,

2. specification of responsibilities related to quality,

3. organizational structure,

4. relevant financial, human and information resources,

5. standards and procedures of internal quality assessment,

6. corrective, prevention and improvement actions and:

7. internal documentation and records regarding to the quality assurance.

- The internal quality evaluation lies in the application of corresponding standards and procedures; this must be detailed in an internal quality evaluation report and made accessible to the higher education institution's managers, as well as to the accreditation body or ministry.

The authors have described, only briefly, the fundamental requirements related to quality, included in the last version of the act-please see [39] for further details.

A relatively new National Accreditation Bureau for Higher Education (hereinafter "Accreditation Bureau") as an independent body was established by the Act No. 111/1998 Coll. (amended and 
consolidated) for Higher Education Institutions and for Amendments and Supplements to Some Other Acts, due to the new requirements related to the overall quality of Czech higher education institutions. What does this really mean for Czech higher education institutions in practice or what implications have occurred with respect to near future?

(1) Any Czech high school or university (private, public or state) must establish a suitable quality management system, which will be evaluated at least every five years by internal evaluation teams and also by external experts nominated through the new Accreditation Bureau, which started its activities in October 2016.

(2) The act does not force a specific type of the quality management system upon the higher education institutions. The concept, extent and maturity of such system is a matter of strategic decision by the top management of certain higher education institutions.

(3) From the authors' own experience (some higher education institutions in the Czech Republic established and developed the quality management systems before the release of the latest version of the Act No. 111/1998 Coll.), Czech higher schools and universities will probably choose between two concepts:

- The ISO 9000 concept,

- The organization's excellence concept.

(4) Our analysis of the current state in the area of quality assurance and quality assessment in Czech higher education institutions proved that education quality (assured through the accreditation process) was the only section of the quality management which was applied there. A system approach to the quality management (where aspects of sustainability are also included) was completely missing.

(5) There is no official and commonly accepted terminology in the area of the quality in higher education.

(6) In spite of the fact that quality is perceived in a different manner, there is common consensus related to the necessity to establish and develop an effective and efficient quality management system, which also covers all assessment activities needed for the accreditation process of Czech universities.

(7) Quality of education is not the same as quality of higher education institution. Quality assurance and quality assessment should cover all processes and outputs of these institutions.

(8) Current trend in area of quality assurance and quality assessment goes beyond the mere requirements of ISO 9001:2015 standard, not only in the production sphere, but also in public service. Moreover, all activities provided by the higher education institution to stakeholders represent public service.

These main implications served as key starting points for our investigations and development activities.

\subsection{Fundamentals of Quality Management in Czech Higher Education Institutions}

Due to fragmented views or opinions related to the basic terminology in the area of quality management, there was an urgency to reach a consensus that promoted understanding and used a unified quality terminology; this was not easy. By way of special seminars and discussions with universities managers (which lasted more than 2 years), the following key definitions were accepted by Czech universities' staff:

Quality: This is the degree to which a set of inherent characteristics of an object fulfils requirements.

Such a definition was accepted from the ISO 9000:2015 [40] standard as the most universal and generic.

Quality management system: an integral part of the overall organization's management system, which guarantees defined functions in the most effective way. 
In this case, a new definition was necessary, to establish whether this term, defined by ISO 9000:2015, is unclear and difficult to understand. As for the functions of the university's quality management system, four functions were identified:

- to maximize all stakeholders' loyalty,

- to promote a culture of continuous improvement and innovations,

- to create the basics of organizational excellence,

- to minimize relevant costs and resource consumption.

The university's quality management system must also include all processes of quality assurance and quality assessment.

Quality assessment: This is a set of internal or external activities providing evidence that a product, service or system conforms to the requirements.

This definition was slightly adapted from ISO/IEC 17000:2004 [41].

The ISO 9000 concept, as well as the organization's excellence concept, was recognized as an appropriate approach to the building and development of the quality management systems within the Czech higher education environment. In particular, the organization's excellence became an attractive alternative because of its sustainability reflection.

\subsection{The Application of Quality Management System Concepts at Czech Higher Education Institutions}

\subsubsection{Application of ISO 9001 Standard at Czech Higher Educational Institutions-A Case Study}

Before the last revision of the Act No. 111/1998 Coll., only a relatively small number of Czech higher education institutions chose to implement the quality management system according to the ISO 9001 standard. Although the reasons for adopting this approach vary from one institution to another, two reasons were common to all institutions:

- $\quad$ an awareness of the benefits of an established quality management system;

- the expectations of legal requirements contained in the forthcoming Act No. 111/1998 Coll. in 2016.

Moreover, these institutions are currently holders of certificates for quality management systems, granted by the current accreditation certification bodies. Therefore, it can be seen as an advantage for them, because they partially meet the requirements of the latest version of the Act No. 111/1998 Coll, presented above in cl. 2 of this article.

The first university which established a quality management system according to the ISO 9001 at Czech Republic was the Technical University of Ostrava-VSB. Some of the lessons learned and related to the establishment and maintenance of the quality management system at this university are described by the authors in the following paragraphs.

The Technical University of Ostrava-VSB is a modern polytechnic education institution, which currently consists of seven faculties: Economics, Civil Engineering, Mechanical Engineering, Electrical Engineering and Computer Science, Mining and Geology, Materials Sciences and Technology and the Faculty of Safety Engineering. All faculties offer structured studies in Bachelor's, Master's and doctoral degree programs, for more than 15,000 students. More than 1500 employees work there and approximately half of them are teachers and staff in the field of science and research.

The competitive environment, as well as the necessity to continually use limited resources more efficiently, contributed to the fact that the top management of the Technical University of Ostrava-VSB decided to implement the quality management system as an integral part of the overall university management system as early as 2003. It was assumed that a well-established quality management system would bring clear benefits, not only for the customers of the university, but also for the university itself and its employees. The quality management system, according to the ISO 9001, was gradually implemented in three stages from 2004-2007. Because each faculty is relatively independent, it was decided to implement the quality management system step by step at individual faculties. As a 
pilot project, the quality management system was established at the Faculty of Electrical Engineering and Computers in 2004. This faculty became the first higher education institution in the Czech Republic to be certified to the ISO 9001 standard. During the second stage (in the years 2005-2006), the quality management system was established at the remaining six faculties and a lot of the experience from the pilot project was introduced. During the last stage, the quality management system was established at other units which support the main processes of the university (the rector's office, the university institutes, the library, the publishing center, the center of information technology, the catering and accommodation services, and others). Finally, in 2007, the university underwent the certification audit as a whole, and the certificates issued for individual faculties were replaced by only one certificate, which covered all activities and products of The VSB-Technical University of Ostrava.

In the very beginning, it was crucial to understand that a university has customers and other stakeholders. Most of the university's people did not realize this fact at all. Quite typically, customers perceive a university's quality through the quality of services that are provided to them by this institution. Therefore, it seemed to be necessary to find the correct answers to the following questions:

1. What are the products of the university?

2. For which customers/stakeholders are such products intended?

3. What are the customers or stakeholders' expectations/requirements from the university?

Table 1 below provides brief answers to these questions. On the basis of the lessons learned, it is possible to say that the set of information in Table 1 is valid, not only for The VSB-Technical University of Ostrava, but also for the majority of higher education institutions.

Table 1. University: its products, customers and their requirements (own work).

\begin{tabular}{ccc}
\hline Product (Characteristics) & Customer & Customer Requirements \\
\hline \multirow{2}{*}{$\begin{array}{c}\text { Bachelor's, Master's and doctoral } \\
\text { education (Obtained qualification) }\end{array}$} & Students & $\begin{array}{c}\text { Preparation for practice, the prerequisites for } \\
\text { obtaining a lucrative job }\end{array}$ \\
\cline { 2 - 3 } & Employers & Fitness for the job title \\
\cline { 2 - 3 } $\begin{array}{c}\text { Lifelong learning } \\
\text { (Deepening or reclassification) }\end{array}$ & Participants & Possibility for career development \\
\cline { 2 - 3 } $\begin{array}{c}\text { Research activity } \\
\text { (Finding new principles and solutions) }\end{array}$ & Community & Opportunities for growth, career change \\
\hline $\begin{array}{c}\text { Cooperation with practice } \\
\text { (Solving specific tasks) }\end{array}$ & Organizations & Applicable solutions, effective solution \\
\hline
\end{tabular}

The establishment of a process approach principle (which is crucial for any advanced quality management) within the university's quality management system was another great challenge. It was necessary to define the processes of The VSB-Technical University of Ostrava, their interrelations and sequence. The main processes (i.e., processes which add value to the products provided) were identified as three major macro-processes:

- Teaching and learning;

- Creative activity;

- Supplementary activity.

The macro-process named as "Teaching and Learning" involves a set of sub-processes and activities focused on the process of teaching and education: Bachelor study, Master study, doctoral study, and last but not least, teachers' self-education and lifelong learning. The macro-process "Creative activity" includes all activities within the area of science and research, or the solution/realization of various research projects, respectively. The process "Supplementary activity" is designed especially 
with the purpose of cooperation and practical application, i.e., cooperation with companies when solving specific tasks (training programs, etc.) These processes can be seen as a universal set for most higher education institutions. However, some schools do not have doctoral study programs, or they are fully oriented only to education, etc. Undoubtedly, these processes can also contribute to the sustainable development, not only of universities, but also of society in general.

In addition to the main processes at The VSB-Technical University of Ostrava, other processes, such as managerial processes, resource management processes, as well as supporting processes, had to be identified. These groups of processes may be specific or unique to individual higher education institutions. Nevertheless, we can find a large number of processes that are common to most universities. For example: the managerial processes at the VSB-Technical University of Ostrava include macro-process "Strategic Management and Improvement". This is divided into two sub-processes: "The creation and updating of a long-term school plan" and "The creation of an annual report". These processes are nonetheless required by specific legislation of the Czech Republic and are compulsory for all higher education institutions. The area of resource management processes comprises the following macro-processes: Financial Resources Management, Human Resources Management, Infrastructure Management, Information Resources Management, etc. Additionally, lastly, the supporting processes, which include all support for teaching and learning (mobility, scholarships, accreditation of study programs, accommodation and food services, marketing and communication, etc.)

A substantial part of the work for the implementation of the quality management system was focused on the processing of internal documentation, in accordance with the ISO 9001 standard's requirements. Typically, internal documents have a hierarchical structure. Such a structure is commonly used in the business sector and is transferable to the academic environment.

Three levels of documentation are defined at the VSB-Technical University of Ostrava:

- I. Level: quality manuals, internal university regulations and legal documents;

- II. Level: descriptions of processes;

- III. Level: guidelines of internal functions and control procedures.

Initially, each faculty had its own documents. Step by step, it was revealed that many of the activities performed by the faculties were the same or very similar, and that was why the internal documentation was gradually unified for the whole university. At present, the faculties have their own quality manuals, which refer to the university documents, and when necessary, they can create additional procedures for exceptional activities.

In addition, the nomination of the people responsible for all of the university's processes was another very important task. The deans of the faculties assigned the necessary responsibility and authority to suitable people. However, it is necessary to point out that the identification of those responsible people was a difficult task for most deans.

Following the establishment of a quality management system, it became necessary to regularly assess and review whether the principles and processes of this system are suitable, efficient, adequate and valid. The ISO 9001:2015 standard requires two main tools for this purpose: internal audits and a management review. Internal auditing helps to identify opportunities for improvement and it also assesses the effectiveness and efficiency of all follow-up actions.

The experience from The VSB-Technical University of Ostrava confirmed some relevant results from business practice:

- the higher education institutions must have a sufficient number of trained auditors;

- $\quad$ any follow-up auditors' training should be especially focused on good practice sharing and learning from their own mistakes;

- audit teams should be changed or rotated regularly;

- an appropriate motivation system for auditors should support their proactive approach to auditing,

- $\quad$ all audits should be oriented to the processes' performance and risks. 
The authors are sure that the facts presented above significantly affect the efficiency and effectiveness of internal auditing at higher education institutions.

With respect to the quality management system review, it enables auditors and universities to evaluate the maturity of the overall quality management system on the basis of the objective information inputs (quality goals and their evaluation, feedback from customers and other stakeholders, evaluation of processes' performance, results of internal audits or self-assessment, risk assessing, benchmarking, etc.) An identification of the weaknesses to be considered as areas for further improvement, innovation and changes is the primary objective of the quality management system review. From the beginning, such activities were, to a lesser degree, underestimated by the deans and the rector. However, since that time, they have gradually become aware of the principal importance of a precise and objective management review.

One specific example that the authors wish to highlight was the continual problem of an extremely low response rate taken from the students' satisfaction measurement. Such feedback has been supported by The VSB-Technical University of Ostrava's information system for several years. Each student has the possibility to evaluate each study course and their respective teachers through a special e-questionnaire. In spite of the fact that this part of the information system can be easily accessed, the students' response rate at the end of 2014 was less than $1 \%$. In the wake of the decisions from the management review process in 2014, several improvement measures were taken to increase the students' awareness of the importance of such feedback. For example, one measure now enables the university to record such assessments whenever the students $\log$ in to the portal. The outcome of this measure resulted in a rapid increase of more than $20 \%$ in the response rate of the total number of university students in 2015, thus, such a significant increase can be viewed as a noteworthy improvement.

The quality management system review must also be a part of the self-assessment activities, which represent a modern and comprehensive tool for the objective self-reflection of any organization (see the following part of this article).

It should also be noted that The VSB-Technical University of Ostrava is not the only higher education institution in the Czech Republic at present with an established quality management system according to the ISO 9001 standard.

The experience and lessons learned, obtained and described in this section were confirmed as universal.

\subsubsection{The Application of Excellence Models at Czech Higher Educational Institutions}

One of the serious shortcomings of the ISO 9001 system is the fact that the sustainability concept is completely absent. On that account, The VSB-Technical University of Ostrava became the first higher education institution in the Czech Republic to start its activities within the EFQM Excellence Model implementation in 2005; the Faculty of Mechanical Engineering of this university was awarded the Czech National Quality Award several years ago. In truth, it was the only higher education institution in the Czech Republic which was interested in this concept until 2011. The Ministry of Education, Youth and Sports of the Czech Republic supported a special project, titled "Providing and evaluating quality in the tertiary education sector", from October 2010 to July 2014. This project was introduced as a follow-up activity to the revision of The Higher Education Act (mentioned in the previous section of this article). The authors became members of a special team of experts who focused on the development and verification of comprehensive quality assessment methodology in Czech higher education institutions in this project. The key fundamentals of this methodology were defined, that is:

(a) The complex assessment of the higher education institutions' quality must be a combination of internal and external assessments which cover not only achieved results but primarily the processes, by means of assessing leading and lagging indicators tailored for higher education institutions. See Figure 1. 
(b) The proposed methodology should allow the assessment of high schools or universities as a whole or their particular units (faculties, research centers, etc.)

(c) The internal quality assessment should respect the principles and rules of self-assessment according to [42].

(d) While the internal quality assessment should be organized by the top management of each higher education institution and performed by trained teams of staff, the external quality assessment must be covered by a recognized and accredited body.

(e) The EFQM Excellence Model (version for 2013) was recognized as a principal set of assessment criteria for the comprehensive quality assessment.

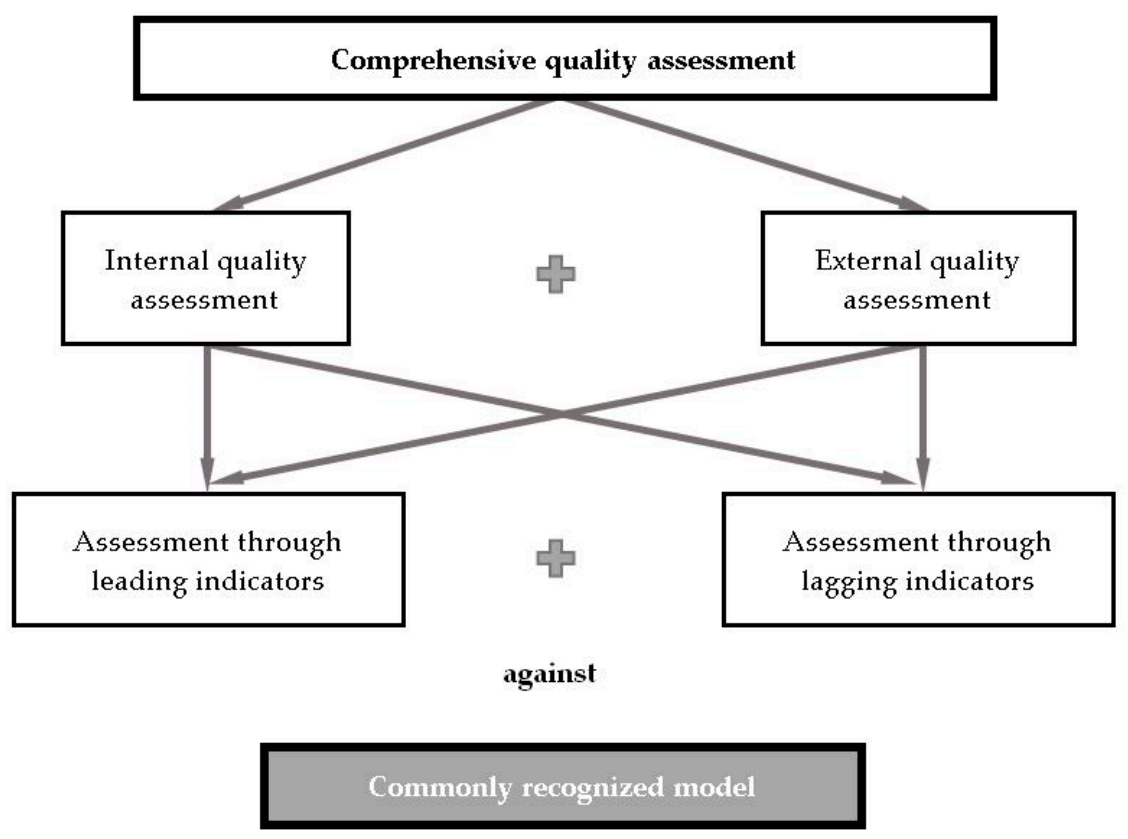

Figure 1. Complex quality assessment framework for Czech higher education institutions (own work).

However, a first testing of the proposed methodology for internal quality assessment, in accordance with the criteria of The EFQM Excellence Model (version 2009), at 12 Czech high schools and universities in 2011 and 2012, revealed one significant fact: the formulations of the assessment criteria of the model was relatively difficult to understand for most people from tested institutions. The risk of a total refusal of the proposed methodology by the whole academic community occurred. Consequently, a new version of the EFQM Excellence Model was published in 2012. For these two serious reasons, we have upgraded and fully adapted all previous 32 partial criteria of The EFQM Excellence Model to the higher education institutions environment. The framework of this set of criteria is presented by Figure 2.

For example, in the main criteria '5-Processes', products and services within enablers' criteria of the model were tailored for academics through the distribution of five partial criteria:

- 5a Education processes are designed, delivered and improved to optimize stakeholder value,

- $5 \mathrm{~b}$ Processes of science and research and other creative activities are designed, delivered and improved to optimize stakeholder value,

- $5 c$ Processes of internationalization are designed, delivered and improved to optimize stakeholder value,

- $5 \mathrm{~d}$ Processes of cooperation with practice are designed, delivered and improved to optimize stakeholder value,

- $\quad 5$ e Customer relationship management processes are designed, delivered and improved to optimize stakeholder value. 


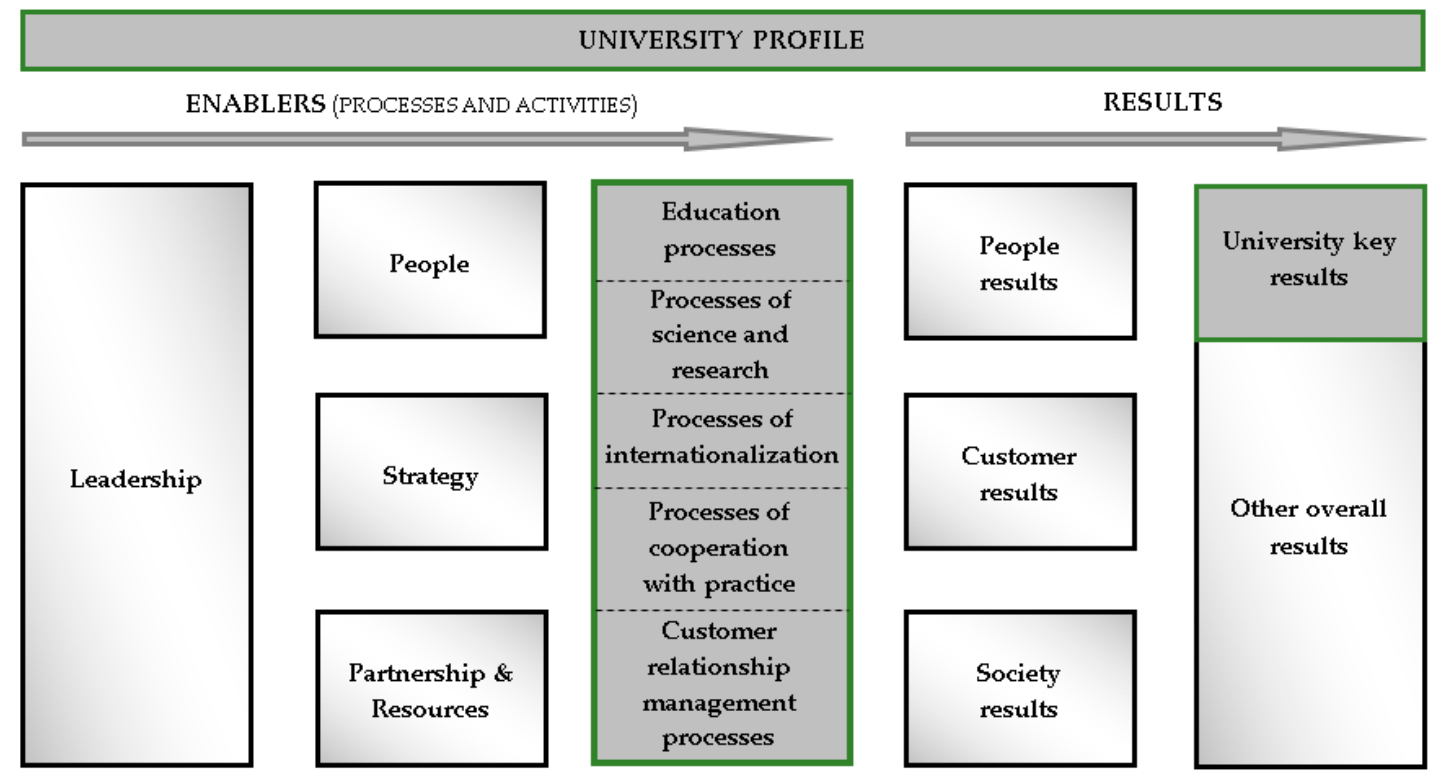

LEARNING, CREATIVITY AND INNOVATION

Figure 2. The framework of criteria for assessing the quality of Czech higher education institution (own work, adapted from The EFQM Excellence Model for 2013 [6]).

A new set of guidance points was designed for each partial criterion naturally. Selection of the guidance points related to the partial criterion 5 a follows and it can serve as an example:

5 a Processes of education are designed, delivered and improved to optimize stakeholder value. Excellent higher education institutions:

- Use the results of the stakeholders' requirements research as input to design and improve the educational processes.

- Design all processes and methods of education with regard to learning outcomes.

- Conduct reviews to determine if their learning outcomes meet the labor market requirements.

- Nominate owners of education processes and exactly define their responsibilities, authority and roles.

- Describe and document educational processes and measure their performance through a suitable set of performance indicators.

- Provide their educational programs with extent and languages according to accreditation to exceed stakeholders' requirements.

- Evaluate students' knowledge and skills by the appropriate manner.

- Take use a benchmarking of educational processes, with the aim to improve their own performance and support innovations.

- Systematically evaluate the quality of study programs.

- Support the educational processes by relevant social services.

- Enforce effective approaches to work with extraordinary talented students, as well as with students with specific needs, etc.

These guidance points were looked upon as a set of recommended leading indicators. The description of all partial criteria was supplemented by a glossary of the relevant terms and a list of possible information resources.

Similarly, a set of lagging indicators was designed for each result criterion. For example, within the scope of partial criterion 9a-Key strategic results (it is included in the main criterion 9-Key university results), two groups of performance indicators were proposed: 
(a) Financial measures, such as:

- Meeting budgets,

- Amount of governmental or funding resources,

- Noncore income generated from other grants, etc.

(b) Nonfinancial measures, such as:

- Number of accredited study programs,

- Number of participants enrolled in the courses of life-long learning,

- Scope of recognized results within research and other creative activities,

- Average value of teachers' performance,

- Average value of key processes' performance,

- Number of exchanged students or staff within internationalization,

- Average number of bibliographic references per person,

- Results of various audits and self-assessment,

- Number of students entered for doctoral study programs, etc.

(c) An in-depth description of assessment criteria was replenished by some other documents, and focused on:

- Guidelines for how to use the assessment criteria in practice,

- Methodology of internal quality assessment,

- Guidelines for how to prepare an internal assessment report,

- E-questionnaire for the first internal quality assessment,

- E-forms for advanced internal assessment,

- Model internal assessment report.

For example, the proposed methodology of the internal quality assessment consists of eleven basic steps, illustrated by Figure 3.

Activity 0 is not considered a natural part of this assessment, but it is a prerequisite for all remaining steps. As without deep engagement of rectors and deans and their active participation in this process, an objective quality assessment can fail. Let us remember that the principle goal of any internal quality assessment is to discover areas for improvement and changes-and each top manager could be keen on discovering such a thing. Any internal quality assessment must be looked upon as a project, and that is why the responsible person from university's top management team must nominate a competent person as a project manager. Naturally, all relevant responsibilities and authorities related to the internal quality assessment should be assigned to the project manager. Thereafter, the project manager is expected to plan all necessary resources (including financial and human resources), the assessment periods, the internal assessment scope, the methods for data gathering, etc. An approved action plan is a key output of this step. As an internal assessment should be a team activity, it is necessary to create a competent internal assessment team. This can be a task for the project manager or for the rector of the university. When a team is nominated, its relevant training must follow. There is no obligatory curriculum; on the contrary, the content and scope of such training depends on the experience of the team members and its knowledge in area of quality assurance and quality assessment. Our personal experience confirms the usual fact, the first internal assessment should be seen as a nice opportunity for team learning and skills gaining. Trained internal assessors should be able to design all materials and aids (as questionnaires) needed for the core assessment. The lead assessor should notify all organizational units of the higher education institution of the assessment goals and procedures, features of the assessment criteria, the assessment schedule, etc. As for the information or data gathering, members of the assessment team can benefit only from two different sources: people and information, systems or documents (guidelines and records). This step can be mostly a very heavy 
going activity (it usually takes more than three months) and the employment of such methods and tools as questionnaires, individual interviews with colleagues, focus groups interview, observations or records analysis can support the effectiveness of this activity. After finishing the data or information gathering, the team of assessors must review if collected data and information are relevant from the point of the quality assessment objectivity and fairness. When discovering the dearth of certain data and evidence, a repeated data gathering should follow. If such repetitions do not produce new data or information, then such an absence should be identified as an area of improvement. On condition that the members of the internal assessment team are experienced, they should be competent to discover a lot of various strengths and weaknesses in the higher education institution's processes and results. All strengths and weaknesses should be objectively presented at an assessment report. All convincing findings should be clearly described at this document. All the described steps should be mandatory for each internal quality assessment. On the other hand, the higher education institution's maturity quantification is only a recommended and voluntary activity. See $[13,43]$ for details.

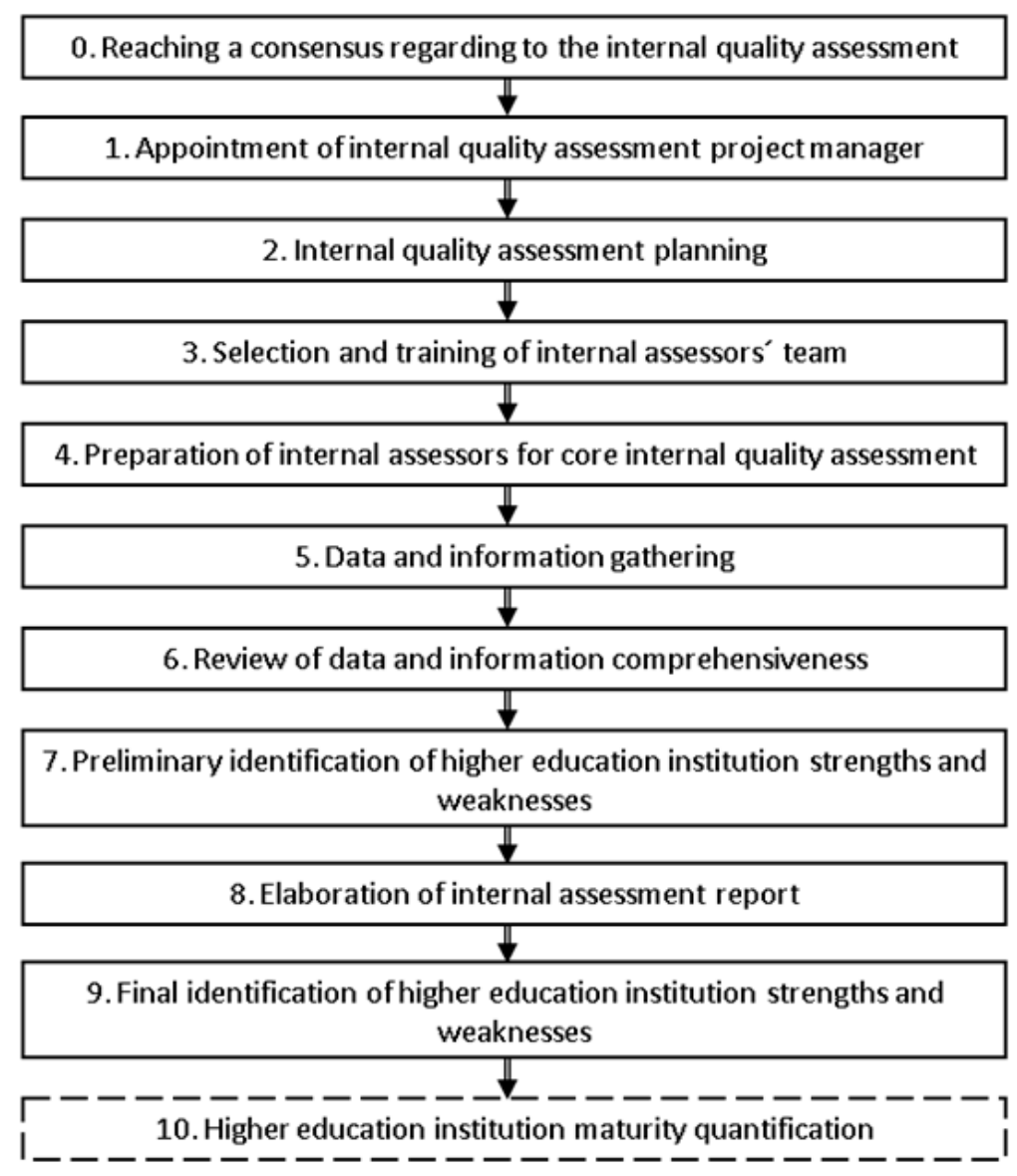

Figure 3. Basic steps of higher education institutions internal quality assessment (own work).

A serious review of the assessment report by the university's top managers is naturally expected. The greatest concern from the point of view of rectors, deans, chancellors, heads of academic boards, etc. is to respond accordingly, quickly and clearly at the appropriate time. The management review process, mentioned above, can serve as a very efficient tool for such a response. Our experience approved, that any internal assessment is a wasted opportunity, if findings presented by the assessment report have no or a late response.

When trying to describe the basic principle of the internal quality assessment, each higher education institution should be assessed from four perspectives: 
(a) Approaches,

(b) Deployment,

(c) Assessment and refinement,

(d) Results.

The "approaches" perspective covers what the higher education institution plans to achieve its intended goals and related results. In particular, the methods used, well defined and implemented processes and the tools of staff work should be investigated there. The "deployment" perspective covers what the higher education institution does to deploy the best approaches. The "assessment and refinement" perspective covers what the higher education institution provides to assess and improve approaches and their real deployment.

While three already mentioned perspectives provide evidence on the higher education institution's potential and capability, on the contrary the "results" perspective is completely focused on indicators which describe what was achieved by the higher education institution. A logic frame RADAR, according to [6,42] could serve as an excellent example for designing and presenting this basic internal assessment principle.

All of the mentioned project outputs were recently tested at various Czech universities in 2013 and the response was definitely positive. These outputs have also undergone international reviews, and all foreign reviewers recommended the described methodologies for practical use at Czech higher education institutions. Presently, all project outputs are available on a special web site of the Ministry of Education, Youth and Sports of the Czech Republic [13]. Some additional information regarding the proposed methodology of the internal quality assessment was also published at [43]. With pleasure, we are able to say that, as a direct response to the project, the Faculty of Agriculture at the University of South Bohemia in České Budějovice was awarded the Czech National Quality Award for the Public Sector in 2015. The VSB-Technical University of Ostrava has developed and established an advanced quality management system according to the adapted EFQM model (see Figure 2) on the foundation of the ISO 9001:2015 requirements. Additionally, the methodology of internal quality assessment presented by Figure 3 is fully accepted as the standard university process now.

\section{Results}

We can summarize the most important findings and the results of our investigation and development:

(a) The quality management (including quality assessment process) was gradually recognized as an important part of overall management system in higher education institutions throughout the world.

(b) Higher education institutions can use a variety of approaches and models as a basis for quality management systems establishing and development. The ISO 9000 family of standards (or their tailored modifications) and various excellence models have already been proved as the most convenient and generic possibility.

(c) The ISO concept lays only fundamentals and it should be firstly used in higher education institutions as an inspiration for initial activities. Unlike excellence models, the ISO concept does not contain sustainability aspects at all.

(d) Therefore, with respect to core sustainability, higher education institutions should prefer some of the excellence models. They represent comprehensive tools which take into consideration all principles, processes, products and services of the higher education institution, include strategic as well as operational activities, and enable the complex assessment of the higher education institution's quality.

(e) On the basis of these common findings, we have designed the comprehensive set of criteria (see Figure 2), that could serve as: 
- Generic guideline on how to develop and improve contemporary management systems in all higher education institutions through an extensive set of guidance points. These guidance points ought to be seen as proved recommendations derived from the best practice, just as in our personal experience;

- The criteria of the internal or external quality assessment when higher education institutions search for the next improvement and development opportunities to assure their ability to sustain long term success.

(f) As the external quality assessment is a matter of authorized assessment bodies (as national accreditation agencies, certification bodies, etc.), we have applied our mind to development of the internal quality assessment scheme and procedures (see Figure 3). However, the steps presented by this figure must be understood only as a common framework, and its adaptation to the concrete higher education institution environment is naturally expected.

(g) The set of criteria, as well as the internal quality assessment methodology (designed and developed by authors of this article), were tested by 12 Czech universities (the sample covered state, public and private universities), and all tested institutions declared positive impacts. These outputs were also reviewed by foreign reviewers, and all of them recommended the described methodologies for practical use.

(h) The lack of real willingness of higher education institutions' managers has occurred as the biggest hindrance to the fair and effective implementation of any approach to quality management. Achieving success in this field is not a matter of money or people knowledge. It is always a matter of proactive leadership and the higher education institution's top managers' involvement.

(i) These tools are regularly used as the framework of the internal quality management by some Czech higher education institutions as The University of South Bohemia in České Budějovice (Faculty of Agriculture), The West Bohemia University of Plzeň, The College of Entrepreneurship and Law Prague, etc. Additionally, naturally, The VSB-Technical University of Ostrava is also deeply engaged in the practical implementation of these tools.

Results and findings, presented above, have universal validity regardless of the type, size or locality of higher education institutions. We can make them generally known now.

Let us also to describe some concrete implications and effects that are tangible in The VSB-Technical University of Ostrava, which was a subject of our case study. One serious effect related to the visible increasing of the response rate in area of the students' satisfaction measurement was highlighted in Section 3.3.1. The mean value of this response rate has been maintained at $15 \%$ since 2015 . However, the implementation of ISO 9001 standards requirements, as well as sequential quality management development based on the adapted EFQM Excellence Model and comprehensive internal quality assessment, has also brought other interesting impacts. We mention only some of them:

- $\quad$ The implementation of the ISO 9001:2015 standards' requirements have created a basic quality culture. The quality of the university was recognized as one of the key success factors and the quality management system was accepted by university's managers as a convenient tool.

- The application of the process approach (which is one of the quality management principles) enabled one to convert a traditional management system to processes oriented management: processes were identified, clearly described, and are maintained and improved in a continuous manner at present.

- Needed authorities and responsibilities were assigned to all the university's managers and processes owners.

- The internal quality auditing, especially focused on processes, discovered some performance gaps and led to the identification of possible improvement (an establishment of the processes of risk/opportunities assessment can serve as a nice example). 
- First, systematic feedbacks from students were established and outputs of these feedbacks also initiated a lot of improvement activities, including the upgrade of the university's information systems.

- $\quad$ Thanks to these activities, the overall university's management system became very transparent and accessible for all university staff. A management manual, including a process map and all quality management procedures, is now available through the special information system. Briefly, it is important to say: the ISO 9001 standard helped to induce a certain level of order within all organizational units of the university.

- A proven quality management system emerged to be an important competitive advantage when university participates in a project tendering, including the projects granted through the European Union funds.

- It is necessary to emphasize that the top management of the university did not recognize the quality management system certification against ISO 9001:2015 as an aim. It was seen only as a certain step on a long journey to excellence and sustainability. Direct rector's support allowed to continue by way of the excellence framework criteria adaptation. Additionally, the methodology of the internal quality assessment, presented in Section 3.3.2, has become a natural part of university life.

- We are sure that the current state of the quality assurance and the quality assessment allowed the quick authorization process of the so-called institutional accreditation of The VSB-Technical University of Ostrava according to the Act No. 111/1998 Coll. [39] This enables the university to now independently create and implement a certain type of degree program in determined fields of study.

- Unfortunately, this qualitative description can be supplemented only by a limited number of a performance indicators at this time. Such a set of information is mostly considered as confidential and we have no permission to present them minutely in this paper. Despite this fact, we can present some of them:

- Student's satisfaction level has been permanently increasing since 2015. It has risen from $77 \%$ to $84 \%$.

- As for the companies' satisfaction level monitoring (as companies are consumers of the university's research and development activities), the mean value has varied from 1.04 to 1.1 over the last four years; 1.0 is optimum.

- Every year, The VSB-Technical University of Ostrava has to undergo external quality audits. No minor or major nonconformities have been identified by external auditors since 2016.

- The share of foreign students (with regard to the total number of the university's students) is ever increasing: while the share was $6 \%$ in 2012 , it is now more than $16 \%$.

Moreover, on a positive note, The VSB-Technical University of Ostrava was awarded the Czech National Award for Social Responsibility in November 2019. The university ranked first in the category 'Public sector with more than 50 employees'. At the same time, the university received the internationally recognized award, "Committed to Sustainability 2 Star". The VSB-Technical University of Ostrava thus confirms the fact that aspects such as performance, sustainable development or corporate social responsibility are an integral part of the university's quality management system.

\section{Discussion and Conclusions}

Do universities need a quality management system? Such a question seems to be lost at present, because one of the answers is definitely yes. All discussions should be focused only on approaches to such a system's development, establishment and improvement $[16,18,20,21]$. Furthermore, our approach was limited; the subjects in this study were not the only cases or people that this methodology could apply to. As we mentioned earlier, higher education institutions have more approaches in this area. The ISO 9000 family of standards or various excellence models was recognized as the most 
frequent possibility. One can argue that universities cannot be managed as industrial companies or that the rigid implementation of ISO 9001:2015 standard's requirements is efficient only at the production or business area. We consider that this is a problem of these requirements' understanding and interpretation. Our experience revealed that this method can be helpful. Additionally, the findings published in [44] testify to this. On the other hand, there are some shortcomings and limitations of the ISO 9001 approach and we discussed them in Section 3.3.2 earlier. Anyway, we must be aware of the fact that any organization must have some management system, regardless of what the products and internal processes are. Additionally, then, the quality management systems fulfil all generic management principles and rules, like leadership, customer orientation, process approach, decision making based on facts, etc. [40] The specific universities' products were presented by Table 1 and the universities' processes were also described in Section 3.3.1. It is obvious the quality management system must take into consideration all the specific features of the higher education institutions' environments. From this point of view, we have opted for The EFQM Excellence Model as a very appropriate tool. It represents the most advanced, comprehensive and modern basis for higher education institutions' management system development. It is not only our personal belief; it can be proven by a lot of experience from abroad. We are sure that Sheffield Hallam University can serve as a nice example of good practice in this field. See also [45-47] for other positive findings. All authors confirm that:

- The EFQM Excellence Model provides a common framework and managerial language in the field of quality management, which is additionally easy to understand.

- It can be used to compare the higher education institution's performance in all areas of interest, using a similar assessment framework.

- It allows the higher education institutions to focus on specific areas for the next improvements and changes, and learn from others who have had similar learning experiences in the past.

- It also supports all higher education institutions to assess how well they are actually doing in comparison to other schools, and whether they are actually the "better or best in class" in quality of education, research activities, etc. Benchmarking is, in fact, viewed as an important part of the journey to the comprehensive universities' excellence.

However, let us to underline that The EFQM Excellence Model gives a special emphasis to the sustainability principles [48]. Additionally, these principles should also be respected by all higher education institutions. In our experience, The EFQM Excellence Model covers all three areas of sustainability: economic, social and environmental. Moreover, a study by Jankalová and Jankal [49] demonstrates this.

That is why we can fully recommend the creative application of all the EFQM Excellence Model's criteria into the higher education institution's management system. Additionally, starting activities supported by the ISO 9000 family of standards could be a way to do this.

Anyway, there is one key precondition of such an application: the active participation and involvement of a higher education institution's top management. Leadership and overall managerial culture are crucial aspects of success when developing efficient and effective quality management in universities. Such a conclusion is also supported by a set of evidence published in $[44,50,51]$.

The principal objective of this article was to present the approaches to quality management systems' development and their assessment at universities, and share some lessons learned from this area of research. It is likely that the awards for the University of South Bohemia in České Budějovice (Faculty of Agriculture) and The Technical University of Ostrava-VSB will not be exceptions. It is clear that under the revised version of The Higher Education Act, all Czech higher education institutions and universities will have to establish, maintain and assess some type of quality management system. The authors have described some facts and lessons learned and related these to the approaches of internal quality assessment at Czech higher education institutions. Undoubtedly, such assessments should be understood as an important part of any quality management system. We hope that the managerial implications and positive impacts of comprehensive quality management and assessment 
are a valuable inspiration for other higher education institutions; not only in the Czech Republic, but also abroad. In fact, the lessons learned and the impacts have universal validity. Our study has also discovered another aspect: there is a close linkage between quality and sustainability: if the higher education institution strives to be sustainable, it must be opened up to all the impulses and trends in the area of advanced quality management.

Naturally, as members of teaching staff, we can also reveal some critical items or weaknesses of the current state in the area of quality management and quality assessment in The VSB-Technical University of Ostrava. An increased level of workload associated with various evaluations, inspections and assessments is perceived unfavorably by the majority of the university's staff. We also observe a certain tendency for formality or attempts to underestimate the objectivity and fairness of the internal quality assessment which occur from some faculties. Moreover, the provision of necessary resources has shown a slightly adverse trend over the last two years. The maintenance and next development of the established quality management system will depend on the university's top managers' attitudes. However, we cannot afford to ignore some external requirements in the area of higher education institution quality or to return to a past time.

We are aware of the next quality challenges; these formulate a scope for future research in this field. Now, we are able to identify four interesting areas of development:

(a) To provide extensive benchmarking oriented to the quality management performance of higher education institutions. Truthfully, there is a poor willingness to participate in such research, from the point of Czech universities' top managers.

(b) To adapt the latest version of the EFQM Model, which was launched some months ago. This version enforces the strategic management of all organizations and extensive feedback loops from all stakeholders [52,53].

(c) It is important to create and implement a closed-loop quality management system as an efficient mixture of internal, external, horizontal and vertical information loops, within higher education institutions and towards all relevant stakeholders. Such loops promote current quality management, and are based on advanced information systems. See [54-56] for more details.

(d) To implement the principles and activities of an object-oriented quality management [57], in the case of the development of a certain study program, and incorporate it into current quality management systems in higher education institutions.

The challenges and areas of future research are really much more than they appear. We should all strive to convert the traditional quality management to a quality of management; quality of management is a crucial precondition for a higher education institution's sustainability and long-term success.

Author Contributions: Conceptualization, D.V., M.F. and J.N.; Data curation, D.V.; Formal analysis, D.V., M.F. and J.N.; Funding acquisition, D.V., M.F. and J.N.; Investigation, D.V., M.F. and J.N.; Methodology, D.V. and J.N.; Project administration, D.V.; Resources, D.V., M.F. and J.N.; Supervision, D.V., M.F. and J.N.; Validation, D.V. and J.N.; Visualization, D.V. and M.F.; Writing-original draft, D.V. and M.F.; Writing-review \& editing, D.V., M.F. and J.N. All authors have contributed equally to this paper. All authors have read and agreed to the published version of the manuscript.

Funding: This research was funded by the specific research project DEVELOPING OF APPROACHES TO MEETING THE REQUIREMENTS OF THE NORMATIVE BASE FOR ADVANCED INTEGRATED MANAGEMENT SYSTEMS, SP2019/129, which was solved at the Faculty of Materials Science and Technology, VŠB-Technical University of Ostrava, with the support of the Ministry of Education, Youth and Sports, Czech Republic.

Conflicts of Interest: The authors declare no conflict of interest. David Vykydal and Jaroslav Nenadál are members of academic staff of The VSB-Technical University of Ostrava, but they are not members of any management teams on levels of departments, faculties or the university as a whole. 


\section{References}

1. ISO 9001:2015 Quality Management System—Requirements; ISO: Geneve, Switzerland, 2015.

2. ISO 9004:2018 Quality Management_Quality of an Organization-Guidance to Achieve Sustained Success; ISO: Geneve, Switzerland, 2018.

3. ISO/IWA 2 Quality Management Systems-Guidelines for the Application of ISO 9001:2000 in Education; ISO: Geneve, Switzerland, 2007.

4. American National Standard: Quality Management Systems Standards-Requirements for Education Organizations; American Society for Quality: Milwaukee, WI, USA, 2011.

5. Standards and Guidelines for Quality Assurance in the European Higher Education Area. Available online: http://www.enqua.eu/wp-content/uploads/2013/06/ESG (accessed on 11 September 2013).

6. EFQM Excellence Model 2013; EFQM Representative Office: Brussels, Belgium, 2012.

7. 2015-2016 Baldrige Excellence Criteria (Education). Available online: http://www.nist.gov/baldrige (accessed on 31 August 2016).

8. The Concept of Excellence in Higher Education. Available online: http://www.enqa.eu/index.php/ publications/ (accessed on 28 August 2016).

9. Adomssent, M.; Godemann, J.; Michelsen, G. Transferability of approaches to sustainable development at universities as a challenge. Int. J. Sustain. High. Educ. 2007, 8, 385-402. [CrossRef]

10. Filho, W.L. Transformative Approaches to Sustainable Development at Universities; Springer International Publishing AG: Cham, Germany, 2016.

11. Webster, M. So What is Organizational Excellence. Available online: https://realorganizationalexcellence.com (accessed on 12 December 2017).

12. What is Organizational Excellence? Available online: www.asq.org/quality-resources/orgnizationalexcellence (accessed on 7 January 2017).

13. Metodika Komplexního Hodnocení Kvality ITV/VŠ. Available online: http://kvalita.reformy-msmt.cz (accessed on 18 September 2016).

14. Kanji, G.K.; Tambi, A.M.A. Total quality management and higher education in Malaysia. Total. Qual. Manag. 1998, 9, 130-132. [CrossRef]

15. Kanji, G.K.; Malek, A.; Tambi, B.A. Total quality management in UK higher education institutions. Total. Qual. Manag. 1999, 10, 129-153. [CrossRef]

16. Watty, K. Want to Know About Quality in Higher Education? Ask an Academic. Qual. High. Educ. 2006, 12, 291-301. [CrossRef]

17. Becket, N.; Brookes, M. Quality Management Practice in Higher Education-What Quality Are We Actually Enhancing? J. Hosp. Leis. Sport Tour. Educ. 2008, 7, 40-54. [CrossRef]

18. Markulík, Š.; Nagyová, A.; Mokrišová, A. Quality management system higher education area. In From Integrated Management System towards Generic Management Systems: Approaches from Slovakia and Germany; Shaker Verlag: Herzogenrath, Germany, 2009; pp. 59-64.

19. Kohoutek, J. Studies on Higher Education. In Implementation of the Standards and Guidelines for Quality Assurance in Higher Education in the Central and East-European Countries-Agenda Ahead; UNESCO-CEPES: Bucharest, Romania, 2009; p. 321.

20. Srikanthan, G.; Dalrymple, J.F. Developing a Holistic Model for Quality in Higher Education. Qual. High. Educ. 2002, 8, 215-224. [CrossRef]

21. Stephenson, J.; Yorke, M. Capability and Quality in Higher Education; Routledge: London, UK, $2012 ;$ p. 224.

22. Zgodavova, K.; Urbančíková, N.; Kisela, M. Enhancement of the Quality Assurance Model at the Slovak University: Case Study. Qual. Innov. Prosper. 2015, 19, 1. [CrossRef]

23. Krause, K.-L.D. Addressing the wicked problem of quality in higher education: Theoretical approaches and implications. High. Educ. Res. Dev. 2012, 31, 285-297. [CrossRef]

24. Schindler, L.; Puls-Elvidge, S.; Welzant, H.; Crawford, L. Definitions of Quality in Higher Education: A Synthesis of the Literature. High. Learn. Res. Commun. 2015, 5, 3. [CrossRef]

25. Hossain, M.M.; Hossain, M.A. Understanding the Quality Management of Private Universities in Bangladesh: A Hierarchical Model. Qual. Manag. J. 2019, 26, 191-206. [CrossRef]

26. Spencer-Matthews, S. Enforced Cultural Change in Academe. A Practical Case Study: Implementing quality management systems in higher education. Assess. Evaluation High. Educ. 2001, 26, 51-59. [CrossRef] 
27. Komotar, M.H. The evolutionary dynamics of quality assurance systems in European higher education: The view from Slovenia. Qual. High. Educ. 2018, 24, 203-220. [CrossRef]

28. Manatos, M.J.; Huisman, J. The use of the European Standards and Guidelines by national accreditation agencies and local review panels. Qual. High. Educ. 2020, 26, 48-65. [CrossRef]

29. Ashour, S.; Fatima, S.K. Factors favouring or impeding building a stronger higher education system in the United Arab Emirates. J. High. Educ. Policy Manag. 2016, 38, 1-16. [CrossRef]

30. Seyfried, M.; Pohlenz, P. Assessing quality assurance in higher education: Quality managers' perceptions of effectiveness. Eur. J. High. Educ. 2018, 8, 258-271. [CrossRef]

31. Noaman, A.Y.; Ragab, A.H.M.; Madbouly, A.I.; Khedra, A.M.; Fayoumi, A.G. Higher education quality assessment model: Towards achieving educational quality standard. Stud. High. Educ. 2015, 42, 23-46. [CrossRef]

32. Tam, M. Measuring Quality and Performance in Higher Education. Qual. High. Educ. 2001, 7, 47-54. [CrossRef]

33. Widrick, S.M.; Mergen, E.; Grant, D. Measuring the dimensions of quality in higher education. Total. Qual. Manag. 2002, 13, 123-131. [CrossRef]

34. Mergen, E.; Grant, D.; Widrick, S.M. Quality management applied to higher education. Total. Qual. Manag. 2000, 11, 345-352. [CrossRef]

35. Atrushi, D.S.; Woodfield, S. The quality of higher education in the Kurdistan Region of Iraq. Br. J. Middle East. Stud. 2018, 45, 1-16. [CrossRef]

36. Dicker, R.; García, M.; Kelly, A.; Mulrooney, H.M. What does 'quality' in higher education mean? Perceptions of staff, students and employers. Stud. High. Educ. 2018, 44, 1425-1441. [CrossRef]

37. Bennett, D.C. Assessing Quality in Higher Education. Available online: https://www.aacu.org/publicationsresearch/periodicals/assessing-quality-higher-education (accessed on 7 November 2019).

38. Morosini, M.C.; Maria Barbosa Fernandes, C.; Leite, D.; Dal Pai Franco, M.E.; Da Cunha, M.I.; Aguiar Isaia, S.M. Quality of Higher Education and the Complex Exercise of Proposing Indicators. Revista Brasiliana de Educacao. 2016. No. 64. Available online: https://www.scielo.br (accessed on 12 January 2020).

39. Act No. 111/1998 Coll. On Higher Education Institutions. Available online: www.msmt.cz/dokumenty-3 (accessed on 11 May 2016).

40. ISO 9000:2015 Quality Management System —Fundamentals and Vocabulary; ISO: Geneve, Switzerland, 2015.

41. ISO/IEC 17000:2004 Conformity Assessment_Vocabulary and General Principles; ISO: Geneve, Switzerland, 2004.

42. Assessing for Excellence; EFQM Publications: Brussels, Belgium, 2013.

43. Nenadál, J. Comprehensive quality assessment of Czech higher education institutions. Int. J. Qual. Serv. Sci. 2015, 7, 138-151. [CrossRef]

44. Adalia, M.; Favaz, A.T. The Effect of ISO 9001 to Oman Higher Education Operational Performance: Buraimi University College as a Case Study. Int. J. Appl. Eng. Res. 2018, 13, 3939-3947.

45. Steed, C.; Maslov, D.; Mazaletskaya, A. The EFQM Excellence Model for Deploying Quality Management: A British? Russian Journey. High. Educ. Eur. 2005, 30, 307-319. [CrossRef]

46. Arjamandi, M.; Kestell, C.; Grimshaw, P. An EFQM excellence model for higher education quality assessment. In Proceedings of the 20th Australasian Association for Engineering Education Conference, University of Adelaide, Adelaide, Australia, 6-9 December 2009; pp. 1015-1020.

47. Steed, D.C. Excellence in Higher Education. Evaluating the Implementation of the EFQM Excellence Model@in Higher Education in the UK. Available online: https://www.bzh.bayern.de/uploads/media/1-2002steed.pdf (accessed on 25 November 2017).

48. Akkucuk, U.; Gencer, Y.G. EFQM Model and Sustainability of Organizations. In Proceedings of the 2nd International Conference on Advances in Management Engineering and Information Technology (AMEIT), Shanghai, China, 23-24 April 2017; pp. 76-79.

49. Jankalová, M.; Jankal, R. Sustainability Assessment According to the Selected Business Excellence Models. Sustainability 2018, 10, 3784. [CrossRef]

50. Davies, J.; Douglas, A.; Douglas, J.A. The effect of academic culture on the implementation of the EFQM Excellence Model in UK universities. Qual. Assur. Educ. 2007, 15, 382-401. [CrossRef]

51. Anyamele, S.C. Implementing Quality Management in the University: The Role of Leadership in Finnish Universities. High. Educ. Eur. 2005, 30, 357-369. [CrossRef]

52. The EFQM Model; EFQM Representative Office: Brussels, Belgium, 2019. 
53. Nenadál, J. The New EFQM Model: What is Really New and Could Be Considered as a Suitable Tool with Respect to Quality 4.0 Concept? Qual. Innov. Prosper. 2020, 24, 17-28. [CrossRef]

54. Goodwin, G. The What, Why, and How of Closed-Loop Quality Processes. Available online: https: //blog.lnsresearch.com (accessed on 3 May 2018).

55. Research Spotlight. Closed-Loop Quality: Connecting Engineering, Manufacturing and Quality. Available online: www.lnsresearch.com (accessed on 14 December 2018).

56. Goulévitch, V. Eight Examples of Properly Working Closed-Loop Quality System. Available online: www.controleng.com/articles (accessed on 13 November 2019).

57. Van Nederpelt, P.W.M. Object-Oriented Quality and Risk Management; Lulu Press: Releigh, NC, USA, 2012; p. 100.

(C) 2020 by the authors. Licensee MDPI, Basel, Switzerland. This article is an open access article distributed under the terms and conditions of the Creative Commons Attribution (CC BY) license (http://creativecommons.org/licenses/by/4.0/). 